\title{
INDIRECT METHOD OF ESTIMATION OF TOTAL FERTILITY RATE AND STUDY ABOUT BIRTHS AVERTED DUE TO FAMILY PLANNING PRACTICES IN INDIA: A RIDGE REGRESSION APPROACH
}

\author{
Piyush Kant Rai ${ }^{*}$, Sarla Pareek ${ }^{2}$, Hemlata Joshi ${ }^{3}$ and Shiwani Tiwari ${ }^{4}$ \\ *Department of Statistics Banaras Hindu University \\ ${ }^{2}$ Department of Mathematics \& Statistics Banasthali University, \\ ${ }^{3}$ Department of Statistics Manipal University Jaipur \\ ${ }^{4}$ Department of Statistics Banaras Hindu University
}

\begin{abstract}
Though, fertility is a biological phenomenon but it depends heavily on socioeconomic, demographic and cultural factors; therefore, this article describes a regression technique to estimate the TFR under dierent proposed model assumptionsand the effects of socioeconomic and demographic factors on TFR as well. The developed methodology also leads to estimate the number of births averted due to the use of family planning methods and percent of increase in births in the absence of birth control devices for 29 states of India using three different methods of births aversion through the National Family Health Survey (NFHS-III) data. The finding shows that there is a variation in number of births averted and percent of increase in births in the absence of family planning methods at the state level in India. The effective use of contraception and maximum number of births avoided due to use of family planning is in Maharashtra and Uttar pradesh. Highest percent of increase in births in the absence of contraception is in Himachal Pradesh and Andhra Pradesh.
\end{abstract}

Keywords : Total fertility rate, General fertility rate, Bongaart's model, Ordinary least square, Multicollinearity, Ridge regression, Births averted, Family planning methods, NFHS.

\footnotetext{
${ }^{*}$ Corresponding author: Piyush Kant Rai email: raipiyush5@gmail.com
} 


\section{Introduction}

The process of human reproduction in traditional societies starts with the consummation of marriage and ends with divorce, menopause or death of either spouse. In demographic contexts, fertility is defined as the actual child bearing performance of a woman or a group of women measured in terms of the actual number of children born rather than the physical capability to produce child which is termed as fecundity.On an average, the reproductive life span of a woman extends over the ages between 15 to 49 years. As fertility is affected by a number of demographic, socio-economic, cultural and biological factors, it is important to understand past, current and future trends of population size, composition and its growth. Information on fertility levels, patterns and trends experienced by a country is important for socio-economic planning, monitoring and evaluating the programs.Canvassing about fertility also provides important information about women's reproductive behaviour and attitudes. Many studies have been carried out to look at fertility variations across countries and explore further to understand factors and indicators influencing fertility level in different segments of population.

No doubt, the crude birth rate (CBR) is a valuable measure of fertility because it directly indicates the contribution of births to the natural growth rate of the population. It is defined as a ratio of the total number of births during a given year to the average (or mid year) population ever lived in the last year. But analytical utility of CBR is reduced as it is affected by several factors, particularly the age-sex structure of the population, distributions of married women in the reproductive period and other characteristics of the population.A better picture of fertility can be obtained by examining the total fertility rate (TFR), it is determined as the number of children which a women of hypothetical cohort would bear during her time of reproduction if she were to bear children through out her life at the rates specified by the schedule of age specific fertility rates for the particular year and if none of them dies before crossing the age of reproduction.

However, in the majority of developing nations, vital registration systems are not good in cov- erage and quality. Moreover, any survey data from these countries, however, carefully planned and executed, are subjected to large errors of omission of events, errors in the identification of the appropriate time period in which the events have occurred, and serious errors in the reporting of the age of the mothers like recall lapse, age heaping etc. in the data. These errors affect the fertility measures such as CBR, TFR up to a great extent. To overcome these difficulties, researchers developed some appropriate technique which is free from the above mentioned errors. The most appropriate technique to estimate the fertility is regression approach.For estimation of total fertility rate, demographers generally used indirect methods namely birth history method and own-child method.The own child method was suggested by 
Cho et al. (1986), which contains reverse survival technique (15 years) for estimating age specific fertility rate (ASFR) from cross-sectional survey.Another indirect technique for estimation of TFR is proximate determinants model, which was given by Bongaart (1978), Bongaart and Potter (1983). They have proposed a simple but guileful method of quantifying the relative effects of the proximate determinants on fertility in a given population.

Brass (1968) suggested a P/F ratio method for estimating fertility and its advancement has been done by Hobcraft et al. (1982), this needs data on last birth history with the age group of the females. Furthermore, stable population method has been used by Rele $(1977,87)$ for estimating TFR and with the use of sample registration system some modification has been done by Swamy et al. (1992).Palmore (1978), Gunasekaran and Palmore (1984) also suggested few regression models to provide estimates of fertility levels indirectly.The continuous increase in use the of contraception nationally and globally implies many unintended pregnancies, as well as induced abortions and maternal deaths, are being prevented (Sai 1992, Khan et al. 1976 and Ross et al. 1999, 2005). Mauldin and Ross (1991), Jain (1997) have used contraceptive prevalence rate (CPR) to predict TFR of any population. Recently, some demographers used data on birth order for estimation of total fertility rate. Some researchers have used proportion of $3+$ order births for estimation of total fertility rate. Yadava et al. (2009) used the weighted average of proportions of different birth orders. A robust regression, include a linear and a quadratic term for CPR (for currently married women) has been done by Li Liu et al. (2008). Singh et al. (2012) used another new predictor variable for estimation of total fertility rate, which is the combination of proportion of females having open birth interval more than 5 years or more and do not use any contraceptive during last 5 years. These predictor variables give quite reliable estimates for TFR but there are a number of factors which affected fertility nega- tively and positively as well such as maternal care, female age at marriage, female literacy rate, human development index, infant mortality rate and birth interval (time between two successive live births) etc. which are correlated with TFR.Thus, the contribution of these predictors in regression model may yield reliable and valid result. 


\section{Birth Aversion and TFR Potential}

The major target of the population programmes and policies is to control the rapid growth of population in most of the populous or high fertile countries, like India. In this context, Promoting family planning methods or use of contraception play wide role to achieve the target in a direct way. Many policies and campaign have been conducted by government for promoting and distributing various modern contraceptive devices. Apart from several organizations, NGOs are also working in this field for promoting the family planning methods especially in those areas, where the use of contraception is less and women are having larger family size. Therefore, it is necessary to know that how much family planning methods are effective to control the population pressure. In this linkage, the main question of the evaluation of the effectiveness of the family planning programme is - how many births have been averted by the use of family planning? In this article, the estimation of births averted due to the use of family planning methods (any method traditional or modern) among 29 Indian states is also done. With the increase of use of contraception devices and implementing various family planning programmes, many attempts has been taken by demographers to estimate the births avoided due to the use of contraception (Mauldin 1968, Potter 1979, United Nations 1982, 1985, Venkatacharya 1971-72, Bhattacharya et al. 1984 and Liu et al. 2008). Several methods have been developed and applied for the estimation of the number of births averted by various researchers in the past and the following three approaches are standard: (1) selected thumb rules (2) Potter's approach using couple- years of effective contraception and (3) various age specific fertility rate approaches (Elena 1975, Liu et al. 2008). The thumb rule is widely used among the above three approaches. In this method, the change in ASFR is multiplied by the average continuation rate for the period but the information before starting of the family planning are not available easily and it may not be reliable. Age specific fertility-rate method / approach require calculating ASFR of women under study at the beginning of the contraception and end of the period. (Kelly 1971) modified this approach slightly and created what is called the "parity approach ". (Elena 1975) had tried to estimate the births averted using the same "parity approach"from primary follow up survey of a family planning clinic which was performed in Cambodia in 1969. Recently, (Liu et al. 2008) suggested three simple methods of estimation for the number of births averted which based on the use of contraceptive. The first method is based on the observed relationship between the general fertility rate (GFR) and contraceptive prevalence rate (CPR) for women who are currently married or in a legal union. The second method is similar to the first but uses the observed relationship between TFR and CPR. The third method is based on the Bongaarts proximate determinants model of fertility. They have estimated number of births that would have occurred in the absence of contraception for 156 countries around the world. 
Estimation of births averted is the procedure to find out the requirement of family planning methods to get rid of the population pressure and for the effectiveness of contraceptive methods. In India, the official family planning programme has started since 1952 and various techniques has been adopted to expand the use of contraception among the couples and as a result there has been a steady increase in the proportion of couples using family planning methods to control their family size. Though, many demographers have attempted to estimate the births averted due to use of family planning methods, but those methods are neither providing better results nor showing the overall impact of contraceptive use in India. Major focus was on the issues of estimation procedure and many of those studies focused only on specific method. From earlier research, it was established that the permanent modern methods like female sterilization, male sterilization and IUD (extensively used in India) are almost 100 percent effective method to prevent pregnancy while other modern temporary methods like condom, pills etc. are not effective method to prevent pregnancy.

Also, it has determined in earlier studies that a significant proportion of women are having unintended or unwanted pregnancies/births and many of those unwanted pregnancies resulted in induced abortion. Induced abortion is not only an economic burden for the women or her family but also the health care system has to be properly equipped with the facilities for abortion. There is also evidence of practice of unsafe abortion, which is sometimes risky for the health of the women. It is very important to estimate the births averted or pregnancies stopped by use of contraception. Maternal and infant deaths are still high in most of the states of India. It is widely recognized that family planning leads to reduce maternal mortality by trimming the number of births and thus the number of times a woman is exposed to the risk of mortality. Therefore, to evaluate the impact of use of family planning methods on maternal and infant mortality, the estimation of births averted provides the basic information that how many women can be saved from experiencing such situation.

Therefore, in this study an attempt has made to estimate the total fertility rate and the births averted along with the use of various contraception methods for 29 states of India by using National Family Health Survey-III data of India. 


\section{Choice of Control Variable(s)}

In the estimation process, choice of control variable(s) plays very significant role. An incompatible choice may provide wage result and sometimes misleading conclusions. Thus a researcher should have brief knowledge about the endogenous variable and associated exogenous vari- able(s), which should explain the data in better way and to have reliable results. The basic requirement in choosing endogenous and exogenous variables is that there should be high correlation between them and data on exogenous variables should be easily obtainable. In this article, number of exogenous variables like, weighted average of proportions of different birth orders, human development index, infant mortality rate, percent of contraceptive use, median number of months since preceding the births, female literacy rate, female age at marriage and maternal care has used for obtaining more reliable and efficient estimates of TFR and corresponding births averted along with the use of various contraception methods for 29 states of India.

\section{Source of Data}

In the analysis, the data on the several variables was taken from National Family Health Survey-III (NFHS-III) about 29 Indian states. The National Family Health Surveys (NFHS) programme, initiated in the early 1990s, has emerged as a nationally important source of data on population, health, and nutrition for India and its states. The 2005-06 National Family Health Survey (NFHS-III), the third in the series of these national surveys, was preceded by NFHS-I in 1992-93 and NFHS-II in 1998-99. Like NFHS-I and NFHS-II, NFHS-III was designed to provide estimates of important indicators on family welfare, maternal and child health, and nutrition. In addition, NFHS-III provides information on several new and emerging issues, including family life education, safe injections, perinatal mortality, adolescent reproductive health, high-risk sexual behaviour, tuberculosis, and malaria. Further, unlike the earlier surveys in which only ever-married women age 15-49 were eligible for individual interviews, NFHS-III interviewed all women age 15-49 and all men age 15- 54. Information on nutritional status, including the prevalence of anaemia, is provided in NFHS-III for women age 15-49, men age 15-54, and young children.

NFHS-III covered all 29 states in India, which comprise more than 99 percent of India's population. NFHS-III is designed to provide estimates of key indicators for India as a whole and, with the exception of HIV prevalence, for all 29 states by urban-rural residence. NFHS-III was conducted under the stewardship of the Ministry of Health and Family Welfare (MOHFW), Government of India, and is the result of the collaborative efforts of a large number of orga- nizations. The International Institute for Population Sciences (IIPS), Mumbai, 
was designated by MOHFW as the nodal agency for the project. Funding for NFHS-III was provided by the United States Agency for International Development (USAID), DFID, the Bill and Melinda Gates Foundation, UNICEF, UNFPA and MOHFW. Macro International, USA, provided tech- nical assistance at all stages of the NFHS-3 project. NACO and the National AIDS Research Institute (NARI) provided technical assistance for the HIV component of NFHS-III. Eighteen Research Organizations, including six Population Research Centres, shouldered the responsi- bility of conducting the survey in the different states of India and producing electronic data files.

\section{Estimation of Total Fertility Rate (TFR)}

In this article, the technique used for estimation of TFR is based on regression analysis. Using the concept of linear regression model, the relationship between total fertility rate and various control variables is demonstrated. (Singh et al. 2012) expressed the results by using ordinary least square estimation (OLS) estimation by looking at the basic assumptions of OLS estimator that the data are taken from normal population and are independent but in statistical literature, there are some other assumptions regarding OLS estimation except as mentioned above for e.g. multicollinearity in exogenous variables and heteroscedasticity in error term. In demographic context, most of the researcher have used only one or two predictor variables to estimate TFR. Since, fertility is affected by various demographic and socio-economic variables thus it would be beneficial to include some more exogenous variables that are moderately or highly correlated with the total fertility rate for better and reliable estimation. In that case, it is essential to check whether the data is free from serious problems related to least square estimation because data suffering from multicollinearity and heteroscedasticity may lead to incorrect or absurd results, moreover, the least square estimates are likely to be too large in absolute value and possibly, of the wrong sign (Al-Hassan 2008). Therefore, least square estimation based upon multicollinearity and heteroscedasticity has considered in this paper.

Analysis for estimation of TFR is done in two ways. In the first, the ordinary least square technique is used to establish the relationship between TFR and control variables without deliberating the assumptions related to the least square estimation and in the second, problems of multicollinearity and heteroscedasticity checked. Here, we started with the first case and consider the model used by (Yadava et al. 2009) for estimation of TFR which is given by

$$
T F R_{1}=\mu+X_{\gamma}
$$

where $X=p_{1}+2 p_{2}+3 p_{3}+\cdots$ and $p_{i}$ is the proportion of $i^{\text {th }}$ order births in the given period or we can say that $X$ is the weighted average of the proportions of different birth orders. And the similar type of regression analysis used by (Singh et al. 2012) for predicting TFR is 
given by

$$
T F R_{2}=\mu+\gamma^{*} N P V
$$

where NPV (additive combination of couple protection rate (CPR) and proportion of currently married females having open birth interval more than 5 years and have not used contraceptives during this period.) is predictor variable, $\mu$ is the intercept term and $\gamma$ is the slop coefficient. Let us consider the matrix notation of regression model,

$$
Y=X \beta+\varepsilon
$$

where $X=\left(x_{i j}\right)$ is a fixed $n \times p+1$ matrix. [ $\left(x_{i j}\right)$ is the $i^{\text {th }}$ observation on the $j^{\text {th }}$ exogenous variable] and is of full rank $p(p \leq n), Y=\left(y_{i}\right)$ is an $n \times 1$ vector of observations on the endogenous variables, $\beta$ is $a p+1 \times 1$ unknown column vector of regression coefficients, and $\varepsilon=\left(\varepsilon_{i}\right)$ is an $n \times 1$ vector of random errors ; $E(\varepsilon)=$ $0, E\left(\varepsilon \varepsilon^{\prime}\right)=\sigma^{2} I_{n}$, where $I_{n}$ denotes the $\mathrm{n} \times \mathrm{n}$ identity matrix i.e. $\varepsilon \sim \operatorname{Normal}\left(0, \sigma^{2} I_{n}\right)$.

Then the least squares (LS) estimator of the parameter is given by

$$
\hat{\beta}=\left(X^{\prime} X\right)^{-1} X^{\prime} Y
$$

Now, using equations (5.1) and (5.2), the relationship between endogenous and exogenous variables are obtained as follows:

$$
\begin{aligned}
& T F R_{1}=-2.216+2.152 X \text { with } R^{2}=.847 \text { and } \\
& T F R_{2}=5.92+2.855 N P V \text { with } R^{2}=.764
\end{aligned}
$$

In the above equations, the values of intercept terms are quite high i.e. -2.216 and 5.92 which is obtained by the method of (Yadava 2009 and Singh 2012) respectively. It shows that some more explanatory variables still excluded in the above models which effects are required to study on TFR. Thus, it is essential to include some more variables in the model to get the reliable and accurate results. Therefore, we have improved our aimed model by adding some important variables that are highly associated to total fertility rate namely, weighted average of proportions of different birth orders (X), human development index (HDI), infant mortality rate (IMR), contraceptive prevalence rate (CPR), median number of months since preceding births as birth interval (BI), female literacy rate (FLR), female age at marriage (FAM) and maternal care (MC) in (Yadava et al. 2009) Thus, the modified regression equation can be written as

$$
Y=\beta_{0}+\sum_{j=1}^{8} B_{j} X_{j}+\varepsilon
$$

where $Y$ is the endogenous variable i.e. TFR and $X_{1}, X_{2}, \ldots, X_{8}$ are the control variables, $\beta_{0}$ is the intercept term. It gives the mean effect on $Y$ of all the variables excluded from the model and $\beta \mathrm{i}^{\prime} \mathrm{s}$ are partial regression coefficients or the slope parameters describing the relation between the endogenous and exogenous variables, on the other hand partial regression coefficients measures the change in the mean value of $\mathrm{Y}$ corresponding to per unit change in 
$\mathrm{X}_{\mathrm{j}}$, when all other control variables are kept constant. Thus, the equation for TFR can be obtained below,

$$
\begin{aligned}
T F R_{3} & =-.241+1743 X-1.207 H D I-.020 I M R-.013 C P R \\
& +.011 B I+.011 F L R-.007 M C+.020 F A M
\end{aligned}
$$

with $R^{2}=.941$. In this case, $R^{2}$ (coefficient of determination) is maximum than the other models used by Yadava et al. and Singh et al. Thus, the above proposed model presented in equation (5.8) will give authentic and true estimate of total fertility rate certainly.

But still, while concerning with the assumptions of linear model, multicollinearity and heteroscedasticity are very serious problems that occur in the data and results obtained by ignoring such type of problems may be misleading and absurd. Therefore, our first step should be to check, whether the data is free from these type of grievous problems. Thus, for determining heteroscedasticity in error term, Breusch-Pagan (BP) test is applied (using R 2.15.0 package) $B P=3.7127$ with $d f=8$ and $p$-value $=0.8821$. The result shows that the data used for analysis is not suffering from the problem of heteroscedasticity but to ascertain whether the two or more exogenous variables in regression model are highly linearly related or not, there are several evidences, shown in the Table 1 (for more detail see Rai et al. 2013) support the presence of multicollinearity in the model. It can be seen that, $R^{2}=0.94$ is quite high, $F=39.444$ with $p-$ value $=0.000$ (highly significant), most of the partial slope coefficients are simultaneously equal to zero, condition number (k) exceeds 1000 i.e. 8499 and $C I=92.19$, this shows that there is severe multicollinearity, and variance inflation factor $(V I F)=10.608$ and 11.876 corresponding to $\mathrm{X}$ (weighted average of proportions of different birth orders) and infant mortality rate (IMR) respectively.

Since data taken for the estimation of TFR has multicollinearity problem, therefore the ridge regression is applied for analysis, also TFR estimation is done by considering weighted average of proportions of different birth orders as a exogenous variable and by using new predictor variable (i.e. the additive combination of CPR and proportion of currently married females having open birth interval more than 5 years and have not used contraceptives during this period) that were used by (Yadava et al. 2009 and Singh et al. 2012) respectively.

The above models used for estimation of TFR are based on ordinary least square estimates but as we have peached about the assumptions to the OLS estimator and also found that our data is enduring with the serious problem of multicollinearity. This means, that the regression models with some degree of collinearity among the regressors and the results computed from the ordinary least squares estimator of the regression parameter poses some problems. This problem has attracted the attention of several authors. Some of them are; (Farrar and Glauber 1967) and (Haitovsky 1969). They have been concerned, essentially, with the testing for the presence and/or the degree of collinearity among the regressors, while others (e.g. Hoerl and Kennard 1970, Feldstein 1973 etc.) have developed alternative estimators when the 
collinearity is moderate and severe. The estimator proposed by Hoerl and Kennard, known as the 'ridge regression (RR) estimator', has gained popularity because of its computational feasibility and some optimality properties (Vinod and Ullah 1981). However, it may have a serious bias. (Hoerl and Kennard 1970a) suggested the use of $X^{\prime} X+k I_{p},(k \geq 0)$ rather than $X^{\prime} X$, in the estimation of $\beta$. The resulting estimator of $\beta$ is known in literature as the $\mathrm{RR}$ estimator, given by

$$
\widehat{\beta(k)}=\left(X^{\prime} X+k I_{p}\right)^{-1} X^{\prime} Y
$$

The constant $\mathrm{k}$ is known as biasing or ridge parameter. For a positive value of $\mathrm{k}$, ridge estimator provides a smaller mean squared error (MSE) compared to least squared estimator (Hoerl and Kennard 1970a). However, the $\operatorname{MSE}(\hat{\beta}(\mathrm{k}))$ will depend on unknown parameters $k, \beta$ and $\sigma^{2}$, which cannot be calculated in practice. But $k$ has to be estimated from the real data instead. Although, the ridge regression estimator is the most popular method for dealing with multicollinearity, though it has drawbacks. The dependence on $k$ tends to result in either instability or bias. As $k \rightarrow \infty, \hat{\beta}(k) \rightarrow 0$ we obtain a stable, but biased estimator of $\beta$. As $k \rightarrow \infty, \hat{\beta}(k) \rightarrow O L S$ we obtain an unbiased, but unstable, estimator of $\beta$. The expected distance between $\hat{\beta}(k)$ and $\beta$ must decrease as $k$ increases from 0 (Al-Hassan, Yazid M. 2008, Yazid M. Al-Hassan 2009). The value of $\mathrm{k}$ that produces the best estimator, however, is not clear. Many different techniques for estimating $k$ have been suggested by different researchers ; some of them are: (Hoerl and Kennard 1970a, Hoerl et al.1975, McDonald and Galarneau 1975, Lawless and Wang 1976, Hocking et al. 1976, Wichern and Churchill 1978, Nordberg 1982, Saleh and Kibria 1993, Singh and Tracy 1999, Wencheko 2000, Kibria 2003, Khalaf and Shukur 2005 and Al-Hassan 2008).

It is evident, that for low or moderate correlations, Geometric Mean ( $\hat{k}_{G M}$ or GM) performs better than the other estimators. However, for high correlations, HKB (Hoerl, Kennard and Baldwin method) performs better than GM and the other estimators. And for extremely high correlation, all estimators (except AM) perform better than or as good as GM (Al-Hassan 2008). Since, there is moderate correlation between exogenous variables therefore, we discussed only $\hat{k}_{G M}$ or GM method of estimation for $k$ in this article. Kibria proposed $\hat{k}_{G M}$ for estimating $k$ by using the geometric mean of $\hat{k}$, which produces the following estimator,

$$
\hat{k}_{G M}=\frac{\hat{\sigma}^{2}}{\left(\prod_{i=1}^{p} \hat{\beta}^{2}\right)^{\frac{1}{p}}}
$$

where $\hat{\sigma}^{2}=\sum e_{i}^{2} / n-p$ and which provides the value of $\mathrm{k}$ as 22.933. Applying equation (5.9), we can easily compute the regression coefficients. Thus, the regression model using ridge regression estimator for estimation of TFR is given as 


$$
\begin{aligned}
\text { FFR }_{4} & =0.0017+0.0735(X)+0.0107(H D I)+0.0213(I M R) \\
& -0.0369(C P R)+0.0173(B I)-0.0399(F L R) \\
& -0.009(M C)+0.0263(F A M)
\end{aligned}
$$

Here, we see that TFR obtained through the method of ridge regression $\left(T F R_{4}\right)$ explains more about TFR and its dependency on many factors than first two approaches $\left(T F R_{1}\right.$ and $\left(T F R_{2}\right)$. The above expression shows, that it is very important to regress TFR on different independent factors including family planning practices in particular, which shows more negative effect on the women fertility behaviour than others ; CPR is a measure of practice of family planning devices so it is necessary to know the effect of contraceptive use to control population explosion. It is helpful to know about births averted by family planning practices. How many births can be averted (How much?) and potential TFR can be identifiable using family planning practices.

\section{Estimation of Number of Births Averted by using Family Planning}

\section{Methods}

Recently, socialization and westernisation is widely being adopted by Indian women and it has huge impact on their reproductive preferences. The demand for small family became more pronounced nowadays as compared to the past. Majority of the couples desire to have fewer children and to fulfil their desire they have the means to control their family size in the form of various methods of contraception. Therefore, the proportion of couples using contraception has increased steadily within last few years. As contraception plays very important role in fulfilling the desire to control family size or to have fewer children, it is essential to estimate the number of births avoided due to contraception. There are three simple methods for estimating the number of births averted developed by (Li Liu et al. 2008). The first method is based on the observed relationship between the general fertility rate (GFR) and contraceptive prevalence rate $(\mathrm{CPR})$ for women who are currently married, CPR(CMW). The second method is similar to the first but uses the observed relationship between total fertility rate (TFR) and CPR (CMW) and the third method is based on the Bongaart's proximate determinants model of fertility (Bongaart 1982) given in Table 2.

The main task for estimation of number of births averted through the use of family planning methods (modern and traditional methods), is to estimate the potential TFR. Therefore, to estimate the potential TFR i.e. the TFR that married women of reproductive age would have experienced in the absence of any contraceptive use, we have regressed TFR on $\mathrm{CPR}$ and various contraceptive methods. The two variables regression model is given by

$$
Y=\beta_{0}+\beta_{1} X+\epsilon
$$


where $\epsilon$ denotes a stochastic variable with some specified probability distribution. The purpose of $\epsilon$ term is to characterize the discrepancies that emerge between the actual observed value of $\mathrm{Y}$ and the values that would be given by an exact functional relationship. Using the method of least square, regression coefficients and error term can be easily calculated. The estimated model can be written as

$$
Y=\beta_{0}+\widehat{\beta_{1}} X+\hat{\epsilon}
$$

Here $\widehat{\beta_{0}}, \widehat{\beta_{1}}$ and $\hat{\epsilon}$ leads to the estimated values of regression coefficients and disturbance term respectively. This linear relationship between dependent and independent variables shows that the change in the mean value of $\mathrm{Y}$ corresponding to per unit change in $\mathrm{X}$ and we have already assured that $\beta_{0}$ gives the average effect on $\mathrm{Y}$ of all the variables excluded from the model. Thus if we put $X=0$ in equation (6.2) or in the absence of $X$, the remaining part i.e. give the $\widehat{\beta_{0}}+\hat{\epsilon}$ will maximum value of $Y$.

In the present study, for estimation of births averted, TFR is taken as dependent and CPR as independent variable. Hence, our model can be written as

$$
T F R=\beta_{0}+\widehat{\beta_{1}} C P R+\hat{\epsilon}
$$

Usine data, we get TFR $=5.066-0.044 \mathrm{CPR}+\hat{\epsilon}$ and $\hat{\epsilon}$ can be easily calculated i.e. $\hat{\epsilon}=T F R-(5.066-0.044 C P R)$. Finally, in the absence of CPR or we can say that if contraceptive use is absent in women/man between age group 15-49, for different values of $\hat{\epsilon}$, the possible TFR (TFR potential) will be equivalent to $5.066+\hat{\epsilon}$. Therefore, it can be easily calculated, defined as the TFR that currently married women of reproductive age group would have experienced if they never used any family planning method and observed TFR is the actual TFR (TFR actual) in presence of current level of contraceptive prevalence rate (CPR). Now, the number of births averted using CPR and percent increase of births in the absence of contraceptive use is given as (Liu et al. 2008)

$$
\text { No. of Births A verted }(\mathrm{BA})=\left(\frac{T F R_{\text {potential }_{i}}}{T F R_{\text {actual }_{i}}}-1\right) * \text { Births }
$$

Percent Increase (PI) of Births

$$
=\left(\frac{T_{F R_{\text {potential }_{i}}}-T F R_{\text {actual }_{i}}}{\text { TFR }_{\text {actual }_{i}}}-1\right) * 100
$$

where i refers to the $i^{\text {th }}$ state of India. Similarly, the number of births avoided using family planning methods and percent increase of births in the absence of contraceptive prevalence rate can be calculated by using the relation between general fertility rate (GFR) and contraceptive prevalence rate (CPR). The results obtained through three methods are shown in Appendix. 


\section{Conclusion}

This study is an attempt to estimate the total fertility rate using indirect method of estimation. Here, ridge regression estimator is used for this purpose where exogenous variables are correlated to each other. Also, estimation of number of births avoided using various family planning methods and percent increase of births in the absence of contraception are studied. The work is done for 29 states of India and data is taken from National Family Health Survey (2005-06). Since total fertility rate depends on various factors i.e. human development index, literacy, maternal care, contraception use, birth interval etc. therefore an improved model is also applied for estimation of TFR. Table 3 given in the Appendix represents the observed and estimated total fertility rate from various indirect methods. The model T F R4 given in equation 5.11 represents the better estimates of TFR as it includes various exogenous variables than others which includes the case of multicollinearity between exogenous variables as well.

From various survey reports and literatures, it is evident that there is variation in the use of contraception at state level in India and the same is shown in Table 4, the findings of this study also showing the variation in number of births averted and percent increase of births at the state level in India (shown in Appendix form Table 5 to Table 9). The estimation of births averted provides not only an approximation of number of births that may occur if the men / women had not been prevented by use of contraception, but also, shows that the use of contraception has significant impact on reducing the fertility level. It can also be concluded that it is highly important to implement sterilization effectively. As, even if the sterilization is fully effective method and use of sterilization is more but still if this method is not properly practiced then the effect of this method for birth aversion cannot be satisfied and thereby the target to reduce fertility level cannot be achieved in the way that can be expected.

Here, in the study contraceptive prevalence rate (CPR) is used in the percentage for the women aged 15-49 years who are using contraceptive methods. CPR for any method considered here is the percentage of women aged $15-49$ years who are using contraceptive method. The methods such as female sterilization, male sterilization, pills, IUD and condom are generally considered as modern contraceptive methods while rhythm and withdrawal etc. methods are considered as traditional methods. CPR for any method includes both modern as well as traditional methods and the use of modern contraceptive methods are higher than the traditional methods in all the states of India. The study demonstrates that the use of modern contraceptive methods is more prevalent as compared to traditional methods. Use of modern contraceptive methods are more in Himachal Pradesh (71\%) and Maharashtra (64.9\%) while the use of traditional methods are high in Assam (29.1\%) and Manipur (25.1\%) (lower than the modern methods) and the number of births averted by modern methods are 
lower in Himachal Pradesh than Maharashtra, Andhra Pradesh, Uttar Pradesh, Tamil Nadu, Madhya Pradesh etc. while the use of contraception is high in Himachal Pradesh in all states of India, this indicates that people in Himachal Pradesh is not using the modern methods in a effective manner. CPR (for any methods-modern or traditional) are higher in Himachal Pradesh (72.6\%) and West Bengal (71.2\%) while lowest in Meghalaya (24.3\%) and Nagaland (29.7\%) (see Table 4). The analysis depicts that the maximum number of births averted using modern family planning methods are in Maharashtra and Andhra Pradesh and by traditional methods, Uttar Pradesh, West Bengal, Assam and Manipur have the maximum number of estimated births averted from both the methods (method 1 and method 2) as shown in Tables 5 and 7. The study indicates that the states Uttar Pradesh, West bengal, Assam and Manipur use the traditional methods in very effective manner. Using total contraceptive prevalence rate (any method), Maharashtra and Uttar Pradesh are showing maximum number of births averted due to all three methods followed by Andhra Pradesh while Meghalaya and Arunachal Pradesh show minimum number of births averted as given in Tables 5 and 7 using modern methods of contraception and total contraception prevalence rate. The effectiveness of modern methods of family planning is more in Maharashtra than any other states of India while high effect of over all contraception prevalence rate can be seen in Maharashtra and Utter Pradesh followed by Andhra Pradesh. Percent increment of births in the absence of modern methods of contraception will be higher than the traditional methods of contraception which is seen in the present study. According to the analysis, the highest percent increase of births in the absence of Contraception (any method) are in Himachal Pradesh and Andhra Pradesh obtained by using all the three methods shown in Appendix (see Tables 6, 8 and 9).

The above findings indicate that there are variation in the number of births avoided using contraception among all states of India. It is not only due to the use of contraception or the size of the population of the states but also vary due to the variation in the use of modern and effective contraceptive methods or due to the effective uses of these methods. Some of the Indian states (Andhra Pradesh, Karnataka, Tamil Nadu \& Maharashtra), the modern method of contraception used by the couples is female sterilization more than $50 \%$ of the other temporary modern methods. 


\section{References}

[1] Al-Hassan, Y.M.(2008). A Monte Carlo evaluation of some ridge estimators. J.J. Appl. Sci: Natural Sciences Series 10(2): 101-110.

[2] Bhattacharya, B.N., Singh, K.K., Taskar, A.D. and Srivastava, O.P. (1984). Births averted under family planning programme: a mathematical approach. Sankhy:The Indian Journal of Statistics 46(3): 320-330.

[3] Bongaart, J. (1978). A frame work for analysing the proximate determinants of fertility. Population and Development Review 4: 105-132.

[4] Bongaart, J. and Potter, R.G. (1983). Fertility, biology and behaviour. New Yark:Academic Press.

[5] Brass, W. (1968).Methods of analysis and estimation. Princeton: Princeton University Press.

[6] Cho, L.J., Retherford, R.D. and Choe, M.K. (1986).Own-Children method of fertility estimation. Honolulu: University of Hawaii Press.

[7] Elena, P.S. (1975). Estimate of births averted in the profamilia program. Studies in Family Planning 6(5): 121-125.

[8] Polat, E. (2018). Determination of the Effective Economic and/or Demographic Indicators in Classification of European Union Member and Candidate Countries Using Partial Least Squares Discriminant Analysis. Journal of Data Science 18: 79-92.

[9] Farrar, D. and Glauber, R. (1967). Multicollinearity in regression analysis: the problem revisited. Review of Economics and Statistics 49: 92-107.

[10] Feldstein M. (1973). Multicollinearity and the mean square error of alternative estimators. Econometrica 41(2):337-346.

[11] Gunasekaran, S. and Palmore, J.A. (1984). Regression estimates of the gross reproduction rate using moments of the female age distribution. Asia and Pacific Census Forum 10(4): 5-10.

[12] Hobcraft, J.N., Goldman, N. and Chidambaram, V.C. (1982). Advances in the P/F ratio method for the analysis of birth histories. Population Studies 36(2): 291-316.

[13] Hocking, R.R., Speed, F.M. and Lynn, M.J. (1976). A class of biased estimators in linear regression. Technometrics 18(4): 425-437. 
[14] Hoerl, A.E. and Kennard, R.W. (1970a). Ridge regression: biased estimation for non-orthogonal problems. Technometrics 12(1): 55-67.

[15] Hoerl, A.E., Kennard, R.W. and Baldwin, K.F. (1975). Ridge regression: some simulation.Communications in Statistics 4(2): 105-123.

[16] Jain, A. (1997). Consistency between contraceptive use and fertility in India. Demography India 26(1): 19-36.

[17] Khan, M.Y., Kirkham, D. and Handy, R.L. (1976). Shapes of Steady State Perched Ground-water Mounds. Water Resources Research 12(3): 429-436.

[18] Kelly, W.J. (1971). Estimation of births averted by family planning program: A parity approach. Studies in Family Planning 2(9): 197-201.

[19] Kibria, B.M. (2003). Performance of some new ridge regression estimators. Communications in Statistics-Simulation and Computation 32(2): 419-435.

[20] Khalaf, G. and Shukur, G. (2005). Choosing ridge parameter for regression problems. Communications in Statistics-Theory and Methods 34(5): 1177-1182.

[21] Lawless, J.F. and Wang, P. (1976). A simulation study of ridge and other regression estimators. Communications in Statistics-Theory and Methods 5(4): 307-323.

[22] Liu, L., Stan, B., Tsui, A. and Saifuddin, A. (2008). Three methods of estimating births averted nationally by contraception. Population Studies 62(2): 191-210.

[23] Mauldin, W.P. (1968). Births averted by family planning programs.Studies in Family Planning 1 (33): 1-7.

[24] Mauldin, W.P. and Ross, J.A. (1991). Family planning programs: Efforts and results: 1982-1989. Studies in Family Planning 22(6): 350-367.

[25] McDonald, G.C. and Galarneau, D.I. (1975). A Monte Carlo evaluation of some ridge-type estimators. Journal of the American Statistical Association 70(350): 407-412.

[26] Moza Said Al-balushi, Ahmed, M.S., Mazharul Islam, M. and Khan, M.H.R. (2016). Con- traceptive Method Choices Among Women In Oman: A Mulitilevel Analysis. Journal of Data Science 14: 117-132. 
[27] Nordberg, L. (1982). A procedure for determination of a good ridge parameter in linear regression. Communications in Statistics-Simulation and Computation 11(3): 285-309.

[28] Palmore, J.A. (1978). Regression estimates of changes in fertility: 1955-60 to 1965-75, for most major nations and territories. Papers of East-West Population Institute, NO. 58. Honolulu: East-West Center.

[29] Potter, R.G. (1969). Estimating births averted in a family planning program, In: Behrman, S.J., Corsa, L., and Freedman, R., eds. Fertility and family planning. Ann Arbor, University of Michigan Press, 1969. 413-434

[30] Potter, R.G. (1979). Analysis of reproductive process. In manual IX the methodology of measuring the impact of family planning programmes on fertility. New York: United Nations, 76-96.

[31] Rai, P.K., Pareek, S. and Joshi, H. (2013). Regression analysis of collinear data using r-k class estimator: socio-economic and demographic factors affecting the total fertility rate (TFR) in India. Journal of Data Science 11: 321-340.

[32] Rele, J.R. (1977). Fertility analysis through extension of stable population concepts. Berkely: University of California; 1967, Republished in 1977 by the Greenwood Press, Westport, Connecticut as Population Monograph Series No.2.

[33] Rele, J.R. (1987). Fertility levels and trends in India: 1951-81. Population and Development Review 13(3): 513-530.

[34] Ross, J.A. (1966). Cost of family planning programs in Bernard Berelson (ed.), Family planning population programs: A review of world developments. Chicago: University of Chicago Press, 761-762.

[35] Ross, J.A., Stover, J. and Willard, A. (1999). Profiles for family planning and reproductive health programs: 116 countries. 2nd edn. Washington DC: Futures Group International.

[36] Ross, J.A., Stover, J. and Adelaja, D. (2005). Profiles for family planning and reproductive health programs: 116 countries. 2nd edn. Washington DC: Group International.

[37] Sai, F. (1992). How family planning can save lives in Africa. African Health 14(3): 10-11.

[38] Saleh, A.K. and Kibria, B.M. (1993). Performances of some new preliminary test ridge regression estimators and their properties. Communications in Statistics-Theory and Methods 22(10): 2747-2764. 
[39] Singh, S. and Tracy, D.S. (1999). Ridge-regression using scrambled responses. Metrika 41(2): 147-157.

[40] Singh, K.K., Singh, B.P. and Gupta, K. (2012). Estimation of total fertility rate and births averted due to contraception: regression approach. International Journal of Statistics and Applications 2(5): 47-55.

[41] Swamy, V.S., Saxena, A.K., Palmore, J.A., Mishra, V., Rele, J.R. and Luther, N.Y. RGI. (1992). Evaluating the sample registration system using indirect estimates of fertility and mortality. New Delhi: Registrar General of India; 1992. Occasional Paper (3).

[42] United Nations (UN). (1982). Evaluation of the Impact of Family Planning Programmes on Fertility: Sources of Variance. New York: United Nations.

[43] United Nations (UN). (1985). Studies to Enhance the Evaluation of Family Planning Programmes. New York: United Nations.

[44]United Nations (UN). (2002). Programme of action of the international conference on population and development. accessed online at www.unfpa.org/icpd/reports \&doc/icpdpoae.html.

[45] Venkatacharya, K. (1971). A model to estimate births averted due to IUCDs and sterilizations. Demography 8(4): 491-505.

[46] Venkatacharya, K. and Das, N.P. (1972). An application of a monte carlo model to estimate births averted due to various family planning methods. Sankhy: The Indian Journal of Statistics 34(3): 297-310.

[47] Vinod, H.D. and Ullah, A. (1981). Recent advances in regression models. Marcel Dekker, New York.

[48] Wencheko, E. (2000). Estimation of the signal-to-noise in the linear regression model. Statistical Papers 41(3): 327-343.

[49] Wichern, D. and Churchill, G. (1978). A comparison of ridge estimators. Technometrics 20(2): 301-311.

[50] Yadava, R.C., Tiwari, A.K. and Sharma, S.S. (2009). Indirect measurements of total fertility rate. The Journal of Family Welfare 55(2): 70-73. 


\section{Appendix:}

Table $1: \beta$-Coefficients

\begin{tabular}{|c|cc|c|c|c|cc|}
\hline Model & \multicolumn{2}{|c|}{$\begin{array}{c}\text { Unstandardized } \\
\text { Coefficients }\end{array}$} & $\begin{array}{c}\text { Standardized } \\
\text { Coefficients }\end{array}$ & $\mathrm{t}$ & $\mathrm{p}$-value & \multicolumn{2}{c|}{$\begin{array}{c}\text { Collinearity } \\
\text { Statistics }\end{array}$} \\
\hline & $\mathrm{B}$ & Std. Error & Beta & & & Tolerance & VIF \\
(Constant) & -0.241 & 1.373 & & -0.175 & 0.863 & & \\
X & 1.743 & 0.416 & 0.745 & 4.191 & 0.000 & 0.094 & 10.608 \\
HDI & -1.027 & 1.006 & -0.166 & -1.021 & 0.320 & 0.113 & 8.866 \\
IMR & -0.020 & 0.008 & -0.454 & -2.413 & 0.026 & 0.084 & 11.876 \\
CPR & -0.013 & 0.007 & -0.246 & -2.052 & 0.053 & 0.207 & 4.835 \\
FAM & 0.020 & 0.005 & 0.446 & 3.675 & 0.002 & 0.203 & 4.933 \\
BI & 0.011 & 0.016 & 0.049 & 0.668 & 0.512 & 0.562 & 1.780 \\
FLR & 0.011 & 0.007 & 0.241 & 1.452 & 0.162 & 0.109 & 9.210 \\
\hline
\end{tabular}

$\mathrm{N}=29, \mathrm{R}=97, \mathrm{R}^{2}=0.941$, Adjusted $, \mathrm{R}^{2}=0.917, \mathrm{~F}=39.444$. Condition number $(\mathrm{k})=8499$ and Condition $\operatorname{Index}(\mathrm{CI})=91.19$ 
Table 2 : Estimation Methods of births averted (BA) and percent increase (PI) of births in the absence of contraceptive use

\begin{tabular}{|c|c|}
\hline \multicolumn{2}{|r|}{ Method 1} \\
\hline Item & GFR Regression \\
\hline Data utilized & $\mathrm{W}_{15-49}, \mathrm{CBR}$, Total Population,GFR,CPR(CMV) \\
\hline Estimation technique & Robust regression with quadratic term \\
\hline Proliminor & $C B R$ \\
\hline calculation & $\begin{array}{l}\text { Proportion of women of reproductive age for country } i^{\prime} \\
G F R^{\text {potential }}=G F R^{\text {actual }}-\beta_{1} * C P R(C M W)-\gamma_{2} *[C P R(C M W)]^{2}\end{array}$ \\
\hline Equation for BA & $\mathrm{BA}(1)=\frac{\left[G F R^{\text {potential }}-G F R^{\text {actual }}\right]}{1000} * \mathrm{~W}_{15-49}$ \\
\hline $\begin{array}{l}\text { Equation of } \\
\text { percentage } \\
\text { increase of births }\end{array}$ & $\mathrm{PI}(1)=\frac{B A(1)}{B i r t h s} * 100$ \\
\hline \multicolumn{2}{|r|}{ Method 2} \\
\hline Item & TFR Regression \\
\hline Data utilized & TFR,CBR,Total Population,CPR(CMW) \\
\hline Estimation technique & Robust regression with quadratic term \\
\hline $\begin{array}{l}\text { Preliminary } \\
\text { calculation }\end{array}$ & $T F R^{\text {potential }}=G F R^{\text {actual }}-\beta_{1} * C P R(C M W)-\gamma_{2} *[C P R(C M W)]^{2}$ \\
\hline Equation for $\mathrm{BA}$ & $\mathrm{BA}(2)=\left(\frac{T F R^{\text {potential }}}{T F R^{\text {actual }}}-1\right) *$ Births $/ 1000$ \\
\hline $\begin{array}{c}\text { Equation of } \\
\text { percentage } \\
\text { increase of births }\end{array}$ & $\mathrm{PI}(2)=\frac{\left[T F R^{\text {potential }}-T F R^{\text {actual }}\right]}{T F R^{\text {actual }}} * 100$ \\
\hline \multicolumn{2}{|r|}{ Method 3} \\
\hline Item & Bongarrts Model \\
\hline Data utilized & CPR(CMW),Failure rates,CBR,Total Population \\
\hline Estimation technique & $\mathrm{TFR}=C_{m} * C_{a} * C_{i} * C_{c} * \mathrm{TF}$ \\
\hline $\begin{array}{l}\text { Preliminary } \\
\text { calculation }\end{array}$ & $\mathrm{e}=\sum e(m) * \frac{u(m)}{u}, C_{c}=1-1.08 * e * e$ \\
\hline Equation for BA & $\mathrm{BA}(3)=\mathrm{PI}(3) *$ Births \\
\hline $\begin{array}{c}\text { Equation of } \\
\text { percentage } \\
\text { increase of births }\end{array}$ & $\mathrm{PI}(3)=\frac{1-C_{c}}{C_{c}} * 100$ \\
\hline
\end{tabular}

Note $: e(m)=$ use effectiveness for specific method of contraception $m ; u(m)=$ method specific contraceptive prevalence rate ; $u=\mathrm{CPR}$ (including small methods and sterilization). 
Table 3: Estimated total fertility rate for 29 states of India

\begin{tabular}{|c|c|c|c|c|c|}
\hline S.No. & States & TFR observed & $T F R_{1}$ & $T F R_{3}$ & $\mathrm{TFR}_{4}$ \\
\hline 1 & Delhi & 2.13 & 2.34 & 2.02 & 2.24 \\
\hline 2 & Haryana & 2.69 & 2.47 & 2.69 & 2.38 \\
\hline 3 & Himachal Pradesh & 1.94 & 1.94 & 1.71 & 1.97 \\
\hline 4 & Jammu and Kashmir & 2.38 & 2.86 & 2.33 & 1.69 \\
\hline 5 & Punjab & 1.99 & 2.13 & 1.97 & 2.07 \\
\hline 6 & Rajasthan & 3.21 & 3.21 & 3.28 & 2.98 \\
\hline 7 & Uttaranchal & 2.55 & 2.70 & 2.67 & 2.17 \\
\hline 8 & Chhattisgarh & 2.62 & 3.03 & 2.87 & 2.81 \\
\hline 9 & Madhya Pradesh & 3.12 & 3.16 & 3.06 & 3.05 \\
\hline 10 & Uttar Pradesh & 3.82 & 3.63 & 3.62 & 3.84 \\
\hline 11 & Bihar & 4.22 & 3.44 & 3.95 & 3.95 \\
\hline 12 & Jharkhand & 3.69 & 3.36 & 3.53 & 3.77 \\
\hline 13 & Orrisa & 2.48 & 2.56 & 2.43 & 2.87 \\
\hline 14 & West Bengal & 2.54 & 2.33 & 2.53 & 2.43 \\
\hline 15 & Arunachal Pradesh & 3.03 & 3.39 & 3.23 & 3.00 \\
\hline 16 & Assam & 2.42 & 2.79 & 2.63 & 2.99 \\
\hline 17 & Manipur & 2.83 & 2.73 & 2.62 & 2.37 \\
\hline 18 & Meghalaya & 3.8 & 3.65 & 3.85 & 3.68 \\
\hline 19 & Mizoram & 2.86 & 2.76 & 2.81 & 3.06 \\
\hline 20 & Nagaland & 3.74 & 3.73 & 3.80 & 3.51 \\
\hline 21 & Sikkim & 2.02 & 2.34 & 2.54 & 1.91 \\
\hline 22 & Tripura & 2.22 & 1.92 & 2.00 & 2.88 \\
\hline 23 & Goa & 1.79 & 1.53 & 1.85 & 2.05 \\
\hline 24 & Gujarat & 2.42 & 2.67 & 2.42 & 2.20 \\
\hline 25 & Maharashtra & 2.11 & 2.05 & 2.19 & 2.15 \\
\hline 26 & Andhra Pradesh & 1.79 & 1.86 & 1.83 & 1.98 \\
\hline 27 & Karnataka & 2.07 & 2.18 & 2.18 & 1.91 \\
\hline 28 & Kerela & 1.93 & 1.65 & 1.77 & 2.10 \\
\hline 29 & Tamil Nadu & 1.8 & 1.78 & 1.83 & 1.73 \\
\hline
\end{tabular}


668 INDIRECT METHOD OF ESTIMATION OF TOTAL FERTILITY RATE AND STUDY ABOUT BIRTHS AVERTED DUE TO FAMILY PLANNING PRACTICES IN INDIA: A RIDGE REGRESSION APPROACH

Table 4: Input data for estimation of births averted and percent increase in the absence of family

planning methods

\begin{tabular}{|c|c|c|c|c|c|c|c|c|c|c|}
\hline \multirow{3}{*}{ States } & \multicolumn{8}{|c|}{ Contraceptive Prevalence Rate (in \%) } & \multirow{3}{*}{$\begin{array}{c}\text { Number } \\
\text { of } \\
\text { Births }\end{array}$} & \multirow{3}{*}{ TFR } \\
\hline & \multicolumn{6}{|c|}{ Any Modern Method } & \multirow[b]{2}{*}{$\begin{array}{c}\text { Any } \\
\text { Traditional } \\
\text { Method }\end{array}$} & \multirow[b]{2}{*}{$\begin{array}{l}\text { Total } \\
\text { CPR }\end{array}$} & & \\
\hline & $\begin{array}{c}\text { Female } \\
\text { Sterilization }\end{array}$ & $\begin{array}{c}\text { Male } \\
\text { Sterilization }\end{array}$ & Pills & IUD & Condom & Total & & & & \\
\hline Delhi & 23 & 0.8 & 4.5 & 5 & 22.9 & 56.5 & 10.4 & 66.9 & 697 & 2.13 \\
\hline Haryana & 38.2 & 0.7 & 2.8 & 4.7 & 11.8 & 58.3 & 5.1 & 63.4 & 737 & 2.69 \\
\hline $\begin{array}{c}\text { Himachal } \\
\text { Pradesh }\end{array}$ & 49 & 6.3 & 2.7 & 1.4 & 11.5 & 71 & 1.6 & 72.6 & 604 & 1.94 \\
\hline $\begin{array}{c}\text { Jammu \& } \\
\text { Kashmir }\end{array}$ & 26.3 & 2.6 & 4.7 & 2.7 & 8 & 44.9 & 7.7 & 52.6 & 728 & 2.38 \\
\hline Punjab & 30.8 & 1.2 & 2.9 & 5.5 & 15.5 & 56.1 & 7.2 & 63.3 & 759 & 1.99 \\
\hline Rajasthan & 34.2 & 0.8 & 2 & 1.6 & 5.7 & 44.4 & 2.8 & 47.2 & 1218 & 3.21 \\
\hline Uttaranchal & 32.1 & 1.8 & 4.2 & 1.5 & 15.7 & 55.5 & 3.8 & 59.3 & 454 & 2.55 \\
\hline Chhattisgarh & 40.7 & 3.3 & 1.4 & 0.8 & 2.9 & 49.1 & 4.1 & 53.2 & 966 & 2.62 \\
\hline $\begin{array}{l}\text { Madhya } \\
\text { Pradesh }\end{array}$ & 44.3 & 1.3 & 1.7 & 0.7 & 4.8 & 52.8 & 3.2 & 55.9 & 1944 & 3.12 \\
\hline $\begin{array}{c}\text { Uttar } \\
\text { Pradesh }\end{array}$ & 17.3 & 0.2 & 1.7 & 1.4 & 8.6 & 29.3 & 14.3 & 43.6 & 4453 & 3.82 \\
\hline Bihar & 23.8 & 0.6 & 1.3 & 0.6 & 2.3 & 28.9 & 5.2 & 34.1 & 1484 & 4.22 \\
\hline Jharkhand & 23.4 & 0.4 & 3.8 & 0.6 & 2.7 & 31.1 & 4.7 & 35.7 & 985 & 3.69 \\
\hline Orrisa & 33.1 & 1 & 7 & 0.5 & 3 & 44.7 & 6.1 & 50.7 & 1093 & 2.48 \\
\hline West Bengal & 32.2 & 0.7 & 11.7 & 0.6 & 4.3 & 49.9 & 21.3 & 71.2 & 1569 & 2.54 \\
\hline $\begin{array}{l}\text { Arunachal } \\
\text { Pradesh }\end{array}$ & 22.5 & 0.1 & 8.1 & 3.4 & 2.8 & 37.3 & 5.9 & 43.2 & 490 & 3.03 \\
\hline Assam & 13 & 0.2 & 10.3 & 1.3 & 2.3 & 27 & 29.5 & 56.5 & 968 & 2.42 \\
\hline Manipur & 8.2 & 0.5 & 5.3 & 5.3 & 4.1 & 23.6 & 25.1 & 48.7 & 1212 & 2.83 \\
\hline Meghalaya & 9.5 & 0.1 & 4.9 & 1.5 & 2.4 & 18.5 & 5.7 & 24.3 & 716 & 3.8 \\
\hline Mizoram & 42.9 & 0 & 10.6 & 4.7 & 1.4 & 59.6 & 0.3 & 59.9 & 487 & 2.86 \\
\hline Nagaland & 9.9 & 0 & 4.7 & 5.2 & 2.6 & 22.5 & 7.2 & 29.7 & 1387 & 3.74 \\
\hline Sikkim & 21.2 & 4.5 & 12.8 & 3 & 4.1 & 48.7 & 9 & 57.6 & 423 & 2.02 \\
\hline Tripura & 17.6 & 0.5 & 21.8 & 0.9 & 3.2 & 44.9 & 20.8 & 65.7 & 400 & 2.22 \\
\hline Goa & 25.8 & 0.1 & 1.5 & 2.2 & 7.5 & 37.2 & 11 & 48.2 & 604 & 1.79 \\
\hline Gujarat & 42.9 & 0.6 & 2.6 & 4.4 & 5.8 & 56.5 & 10.1 & 66.6 & 901 & 2.42 \\
\hline Maharashtra & 51.1 & 2.1 & 2.4 & 3 & 6.2 & 64.9 & 1.9 & 66.9 & 1998 & 2.11 \\
\hline $\begin{array}{l}\text { Andhra } \\
\text { Pradesh }\end{array}$ & 62.9 & 2.9 & 0.3 & 0.5 & 0.5 & 67 & 0.6 & 67.6 & 1336 & 1.79 \\
\hline Karnataka & 57.4 & 0.2 & 0.8 & 2.5 & 1.7 & 62.5 & 1.1 & 63.6 & 1284 & 2.07 \\
\hline Kerela & 48.7 & 1 & 0.4 & 2.3 & 5.5 & 57.9 & 10.7 & 68.6 & 611 & 1.93 \\
\hline Tamil Nadu & 55 & 0.4 & 0.2 & 2.1 & 2.3 & 60 & 1.4 & 61.4 & 1016 & 1.8 \\
\hline
\end{tabular}


Table 5 : Estimated number of births averted due to family planning methods using TFR

\begin{tabular}{|c|c|c|c|c|c|c|c|c|}
\hline \multirow{3}{*}{ States } & \multicolumn{8}{|c|}{ Births Averted due to Family Planning Methods } \\
\hline & \multicolumn{6}{|c|}{ Any Modern Method } & \multirow[b]{2}{*}{$\begin{array}{c}\text { Any } \\
\text { Traditional } \\
\text { Method }\end{array}$} & \multirow[b]{2}{*}{$\begin{array}{l}\text { Total } \\
\text { CPR }\end{array}$} \\
\hline & $\begin{array}{c}\text { Female } \\
\text { Sterilization }\end{array}$ & $\begin{array}{c}\text { Male } \\
\text { Sterilization }\end{array}$ & Pills & IUD & Condom & Total & & \\
\hline Delhi & 244 & 25 & 93 & 128 & 258 & 821 & 154 & 968 \\
\hline Haryana & 339 & 20 & 51 & 102 & 114 & 710 & 67 & 768 \\
\hline $\begin{array}{l}\text { Himachal } \\
\text { Pradesh }\end{array}$ & 494 & 172 & 57 & 39 & 127 & 982 & 31 & 1000 \\
\hline $\begin{array}{c}\text { Jammu \& } \\
\text { Kashmir }\end{array}$ & 260 & 71 & 91 & 66 & 86 & 611 & 108 & 712 \\
\hline Punjab & 380 & 43 & 72 & 164 & 205 & 951 & 127 & 1068 \\
\hline Rajasthan & 420 & 31 & 51 & 51 & 78 & 750 & 54 & 792 \\
\hline Uttaranchal & 185 & 30 & 48 & 23 & 97 & 439 & 33 & 467 \\
\hline Chhattisgarh & 486 & 109 & 37 & 28 & 42 & 805 & 73 & 868 \\
\hline $\begin{array}{l}\text { Madhya } \\
\text { Pradesh }\end{array}$ & 894 & 79 & 75 & 43 & 112 & 1463 & 101 & 1541 \\
\hline $\begin{array}{l}\text { Uttar } \\
\text { Pradesh }\end{array}$ & 654 & 28 & 129 & 132 & 349 & 1520 & 734 & 2248 \\
\hline Bihar & 271 & 21 & 31 & 19 & 31 & 453 & 85 & 530 \\
\hline Jharkhand & 202 & 12 & 64 & 15 & 27 & 370 & 59 & 422 \\
\hline Orrisa & 473 & 43 & 194 & 23 & 51 & 876 & 125 & 989 \\
\hline $\begin{array}{l}\text { West Ben- } \\
\text { gal }\end{array}$ & 645 & 46 & 450 & 37 & 99 & 1368 & 577 & 1946 \\
\hline $\begin{array}{l}\text { Arunachal } \\
\text { Pradesh }\end{array}$ & 118 & 3 & 81 & 43 & 17 & 268 & 44 & 309 \\
\hline Assam & 169 & 9 & 254 & 42 & 34 & 479 & 511 & 1000 \\
\hline Manipur & 113 & 19 & 140 & 174 & 61 & 449 & 467 & 923 \\
\hline Meghalaya & 58 & 2 & 57 & 22 & 16 & 156 & 49 & 203 \\
\hline Mizoram & 237 & 3 & 113 & 64 & 11 & 451 & 7 & 451 \\
\hline Nagaland & 119 & 1 & 107 & 148 & 34 & 373 & 120 & 487 \\
\hline Sikkim & 144 & 82 & 165 & 50 & 31 & 453 & 86 & 534 \\
\hline Tripura & 103 & 10 & 242 & 14 & 22 & 359 & 164 & 524 \\
\hline Goa & 282 & 6 & 34 & 60 & 89 & 558 & 166 & 720 \\
\hline Gujarat & 517 & 25 & 65 & 130 & 79 & 934 & 170 & 1097 \\
\hline Maharashtra & 1566 & 186 & 156 & 233 & 217 & 2730 & 104 & 2803 \\
\hline $\begin{array}{l}\text { Andhra } \\
\text { Pradesh }\end{array}$ & 1519 & 201 & 30 & 45 & 29 & 2222 & 41 & 2232 \\
\hline Karnataka & 1152 & 23 & 43 & 130 & 48 & 1723 & 46 & 1745 \\
\hline Kerela & 499 & 32 & 13 & 61 & 65 & 814 & 153 & 961 \\
\hline Tamil Nadu & 1004 & 30 & 18 & 101 & 55 & 1505 & 49 & 1533 \\
\hline
\end{tabular}


670 INDIRECT METHOD OF ESTIMATION OF TOTAL FERTILITY RATE AND STUDY ABOUT BIRTHS AVERTED DUE TO FAMILY PLANNING PRACTICES IN INDIA: A RIDGE REGRESSION APPROACH

Table 6 : Percent increase of births in the absence of some specific methods of contraception using TFR

\begin{tabular}{|c|c|c|c|c|c|c|c|c|}
\hline \multirow{3}{*}{ States } & \multicolumn{8}{|c|}{$\%$ Increase in the Absence of Contraception Method } \\
\hline & \multicolumn{6}{|c|}{ Any Modern Method } & \multirow[b]{2}{*}{$\begin{array}{c}\text { Any } \\
\text { Traditional } \\
\text { Method }\end{array}$} & \multirow[b]{2}{*}{$\begin{array}{l}\text { Total } \\
\text { CPR }\end{array}$} \\
\hline & $\begin{array}{c}\text { Female } \\
\text { Sterilization }\end{array}$ & $\begin{array}{c}\text { Male } \\
\text { Sterilization }\end{array}$ & Pills & IUD & Condom & Total & & \\
\hline Delhi & 35.01 & 3.65 & 13.35 & 18.3 & 37.01 & 117.8 & 22.08 & 138.95 \\
\hline Haryana & 45.96 & 2.73 & 6.87 & 13.79 & 15.43 & 96.29 & 9.08 & 104.27 \\
\hline $\begin{array}{l}\text { Himachal } \\
\text { Pradesh }\end{array}$ & 81.75 & 28.53 & 9.42 & 6.41 & 21.08 & 162.55 & 5.06 & 165.56 \\
\hline $\begin{array}{l}\text { Jammu and } \\
\text { Kashmir }\end{array}$ & 35.78 & 9.71 & 12.47 & 9.04 & 11.85 & 83.88 & 14.78 & 97.77 \\
\hline Punjab & 50.09 & 5.69 & 9.46 & 21.57 & 27.05 & 125.24 & 16.76 & 140.72 \\
\hline Rajasthan & 34.49 & 2.51 & 4.2 & 4.18 & 6.43 & 61.54 & 4.43 & 65.05 \\
\hline Uttaranchal & 40.8 & 6.52 & 10.57 & 4.99 & 21.46 & 96.73 & 7.37 & 102.88 \\
\hline $\begin{array}{c}\text { Chhattisgar } \\
\mathrm{h}\end{array}$ & 50.27 & 11.26 & 3.82 & 2.88 & 4.32 & 83.33 & 7.6 & 89.83 \\
\hline $\begin{array}{l}\text { Madhya } \\
\text { Pradesh }\end{array}$ & 45.96 & 4.07 & 3.85 & 2.23 & 5.76 & 75.23 & 5.18 & 79.26 \\
\hline $\begin{array}{c}\text { Uttar } \\
\text { Pradesh }\end{array}$ & 14.68 & 0.63 & 2.9 & 2.97 & 7.84 & 34.13 & 16.48 & 50.49 \\
\hline Bihar & 18.26 & 1.42 & 2.09 & 1.29 & 2.06 & 30.54 & 5.7 & 35.75 \\
\hline Jharkhand & 20.54 & 1.17 & 6.53 & 1.49 & 2.74 & 37.56 & 5.96 & 42.8 \\
\hline Orrisa & 43.25 & 3.97 & 17.76 & 2.07 & 4.65 & 80.16 & 11.43 & 90.44 \\
\hline $\begin{array}{l}\text { West Ben- } \\
\text { gal }\end{array}$ & 41.13 & 2.9 & 28.66 & 2.35 & 6.32 & 87.17 & 36.78 & 124.01 \\
\hline $\begin{array}{l}\text { Arunachal } \\
\text { Pradesh }\end{array}$ & 24.06 & 0.58 & 16.6 & 8.82 & 3.44 & 54.8 & 9 & 63.07 \\
\hline Assam & 17.46 & 0.98 & 26.24 & 4.36 & 3.51 & 49.5 & 52.83 & 103.29 \\
\hline Manipur & 9.36 & 1.59 & 11.52 & 14.33 & 5.02 & 37.05 & 38.5 & 76.13 \\
\hline Meghalaya & 8.11 & 0.33 & 7.98 & 3.11 & 2.26 & 21.79 & 6.82 & 28.29 \\
\hline Mizoram & 48.57 & 0.57 & 23.18 & 13.06 & 2.23 & 92.63 & 1.38 & 92.66 \\
\hline Nagaland & 8.55 & 0.08 & 7.75 & 10.65 & 2.45 & 26.86 & 8.67 & 35.13 \\
\hline Sikkim & 34.03 & 19.38 & 39.1 & 11.73 & 7.35 & 107.14 & 20.22 & 126.15 \\
\hline Tripura & 25.86 & 2.4 & 60.39 & 3.57 & 5.39 & 89.77 & 41.06 & 130.93 \\
\hline Goa & 46.66 & 1.02 & 5.65 & 9.88 & 14.79 & 92.43 & 27.41 & 119.13 \\
\hline Gujarat & 57.35 & 2.73 & 7.18 & 14.44 & 8.77 & 103.69 & 18.91 & 121.75 \\
\hline Maharashtra & 78.36 & 9.33 & 7.8 & 11.67 & 10.86 & 136.65 & 5.19 & 140.27 \\
\hline $\begin{array}{l}\text { Andhra } \\
\text { Pradesh }\end{array}$ & 113.69 & 15.01 & 2.27 & 3.37 & 2.19 & 166.29 & 3.04 & 167.07 \\
\hline Karnataka & 89.71 & 1.8 & 3.33 & 10.16 & 3.77 & 134.17 & 3.6 & 135.93 \\
\hline Kerela & 81.64 & 5.3 & 2.16 & 9.95 & 10.59 & 133.21 & 25.05 & 157.25 \\
\hline Tamil Nadu & 98.86 & 2.97 & 1.76 & 9.94 & 5.42 & 148.14 & 4.82 & 150.91 \\
\hline
\end{tabular}


Table 7 : Estimated number of births averted due to family planning methods using GFR

\begin{tabular}{|c|c|c|c|c|c|c|c|c|}
\hline \multirow{3}{*}{ States } & \multicolumn{8}{|c|}{ Births Averted due to Family Planning Methods } \\
\hline & \multicolumn{6}{|c|}{ Any Modern Method } & \multirow{2}{*}{$\begin{array}{c}\text { Any } \\
\text { Tradition } \\
\text { al } \\
\text { Method }\end{array}$} & \multirow[b]{2}{*}{$\begin{array}{l}\text { Total } \\
\text { CPR }\end{array}$} \\
\hline & $\begin{array}{c}\text { Female } \\
\text { Sterilization }\end{array}$ & $\begin{array}{c}\text { Male } \\
\text { Sterilization }\end{array}$ & Pills & IUD & Condom & Total & & \\
\hline Delhi & 216.12 & 17.43 & 85.91 & 34.52 & 363.35 & 735.80 & 124.23 & 869.30 \\
\hline Haryana & 299.01 & 12.72 & 44.56 & 27.05 & 156.01 & 632.43 & 51.41 & 686.32 \\
\hline $\begin{array}{l}\text { Himachal } \\
\text { Pradesh }\end{array}$ & 438.93 & 130.50 & 49.18 & 9.27 & 174.01 & 881.35 & 19.73 & 899.42 \\
\hline $\begin{array}{l}\text { Jammu and } \\
\text { Kashmir }\end{array}$ & 242.08 & 55.35 & 87.88 & 18.26 & 124.37 & 572.84 & 90.18 & 669.59 \\
\hline Punjab & 318.07 & 28.69 & 60.87 & 41.72 & 270.32 & 802.94 & 95.00 & 904.05 \\
\hline Rajasthan & 373.42 & 20.25 & 44.41 & 12.88 & 105.15 & 671.86 & 39.74 & 712.76 \\
\hline Uttaranchal & 265.94 & 34.52 & 70.71 & 9.17 & 219.67 & 637.20 & 40.80 & 679.43 \\
\hline Chhattisgarh & 435.02 & 81.58 & 30.44 & 6.33 & 52.39 & 727.33 & 56.48 & 786.42 \\
\hline $\begin{array}{l}\text { Madhya } \\
\text { Pradesh }\end{array}$ & 798.73 & 54.27 & 62.34 & 9.36 & 146.23 & 1319.33 & 75.07 & 1393.93 \\
\hline $\begin{array}{l}\text { Uttar } \\
\text { Pradesh }\end{array}$ & 591.33 & 15.93 & 118.12 & 35.23 & 496.45 & 1388.72 & 616.95 & 2060.95 \\
\hline Bihar & 254.94 & 14.91 & 28.33 & 4.77 & 41.65 & 429.09 & 70.85 & 505.16 \\
\hline Jharkhand & 195.81 & 7.75 & 64.59 & 3.70 & 38.17 & 360.72 & 50.12 & 413.17 \\
\hline Orrisa & 421.58 & 29.50 & 181.12 & 4.74 & 64.58 & 789.10 & 99.19 & 893.09 \\
\hline West Bengal & 613.74 & 30.93 & 452.95 & 8.48 & 138.48 & 1318.81 & 512.79 & 1876.88 \\
\hline $\begin{array}{l}\text { Arunachal } \\
\text { Pradesh }\end{array}$ & 103.96 & 1.08 & 76.01 & 11.54 & 21.86 & 238.88 & 34.73 & 276.06 \\
\hline Assam & 140.03 & 4.98 & 225.33 & 10.28 & 41.84 & 403.69 & 400.16 & 841.78 \\
\hline Manipur & 103.81 & 14.66 & 136.27 & 49.24 & 87.66 & 414.62 & 400.11 & 852.57 \\
\hline Meghalaya & 56.61 & 1.39 & 59.30 & 6.57 & 24.16 & 152.83 & 42.98 & 200.25 \\
\hline Mizoram & 215.55 & 0.04 & 108.19 & 17.36 & 11.91 & 414.99 & 2.72 & 416.26 \\
\hline Nagaland & 108.22 & 0.03 & 104.35 & 41.72 & 48.01 & 340.96 & 99.58 & 448.96 \\
\hline Sikkim & 126.50 & 62.08 & 155.12 & 13.15 & 41.33 & 402.80 & 68.28 & 475.35 \\
\hline Tripura & 94.10 & 6.18 & 236.72 & 3.53 & 28.90 & 332.92 & 140.42 & 485.86 \\
\hline Goa & 250.71 & 2.27 & 29.63 & 15.71 & 123.09 & 501.16 & 135.30 & 647.80 \\
\hline Gujarat & 448.80 & 14.58 & 55.30 & 33.84 & 102.52 & 819.29 & 134.39 & 963.60 \\
\hline Maharashtra & 1338.14 & 127.34 & 127.87 & 57.87 & 274.38 & 2355.16 & 67.17 & 2422.87 \\
\hline $\begin{array}{l}\text { Andhra } \\
\text { Pradesh }\end{array}$ & 1257.80 & 134.21 & 12.36 & 7.51 & 17.06 & 1856.66 & 18.72 & 1869.58 \\
\hline Karnataka & 967.49 & 7.95 & 27.54 & 31.07 & 48.54 & 1459.87 & 26.19 & 1482.60 \\
\hline Kerela & 487.20 & 23.19 & 8.20 & 16.95 & 92.98 & 802.90 & 136.10 & 949.15 \\
\hline Tamil Nadu & 913.28 & 15.48 & 6.87 & 25.70 & 64.61 & 1380.69 & 31.91 & 1410.08 \\
\hline
\end{tabular}


672 INDIRECT METHOD OF ESTIMATION OF TOTAL FERTILITY RATE AND STUDY ABOUT BIRTHS AVERTED DUE TO FAMILY PLANNING PRACTICES IN INDIA: A RIDGE REGRESSION APPROACH

Table 8 : Percent increase of births in the absence of some specific methods of contraception using

GFR

\begin{tabular}{|c|c|c|c|c|c|c|c|c|}
\hline \multirow{3}{*}{ States } & \multicolumn{8}{|c|}{$\%$ Increase in the Absence of Contraception Method } \\
\hline & \multicolumn{6}{|c|}{ Any Modern Method } & \multirow[b]{2}{*}{$\begin{array}{c}\text { Any } \\
\text { Traditional } \\
\text { Method }\end{array}$} & \multirow[b]{2}{*}{$\begin{array}{l}\text { Total } \\
\text { CPR }\end{array}$} \\
\hline & $\begin{array}{c}\text { Female } \\
\text { Sterilization }\end{array}$ & $\begin{array}{c}\text { Male } \\
\text { Sterilization }\end{array}$ & Pills & IUD & Condom & Total & & \\
\hline Delhi & 31.01 & 2.50 & 12.33 & 4.95 & 52.13 & 105.57 & 17.82 & 124.72 \\
\hline Haryana & 40.57 & 1.73 & 6.05 & 3.67 & 21.17 & 85.81 & 6.98 & 93.12 \\
\hline $\begin{array}{l}\text { Himachal } \\
\text { Pradesh }\end{array}$ & 72.67 & 21.61 & 8.14 & 1.53 & 28.81 & 145.92 & 3.27 & 148.91 \\
\hline $\begin{array}{c}\text { Jammu and } \\
\text { Kashmir }\end{array}$ & 33.25 & 7.60 & 12.07 & 2.51 & 17.08 & 78.69 & 12.39 & 91.98 \\
\hline Punjab & 41.91 & 3.78 & 8.02 & 5.50 & 35.62 & 105.79 & 12.52 & 119.11 \\
\hline Rajasthan & 30.66 & 1.66 & 3.65 & 1.06 & 8.63 & 55.16 & 3.26 & 58.52 \\
\hline Uttaranchal & 58.58 & 7.60 & 15.57 & 2.02 & 48.39 & 140.35 & 8.99 & 149.65 \\
\hline Chhattisgarh & 45.03 & 8.44 & 3.15 & 0.65 & 5.42 & 75.29 & 5.85 & 81.41 \\
\hline $\begin{array}{l}\text { Madhya } \\
\text { Pradesh }\end{array}$ & 41.09 & 2.79 & 3.21 & 0.48 & 7.52 & 67.87 & 3.86 & 71.70 \\
\hline $\begin{array}{c}\text { Uttar } \\
\text { Pradesh }\end{array}$ & 13.28 & 0.36 & 2.65 & 0.79 & 11.15 & 31.19 & 13.85 & 46.28 \\
\hline Bihar & 17.18 & 1.00 & 1.91 & 0.32 & 2.81 & 28.91 & 4.77 & 34.04 \\
\hline Jharkhand & 19.88 & 0.79 & 6.56 & 0.38 & 3.87 & 36.62 & 5.09 & 41.95 \\
\hline Orrisa & 38.57 & 2.70 & 16.57 & 0.43 & 5.91 & 72.20 & 9.07 & 81.71 \\
\hline West Bengal & 39.12 & 1.97 & 28.87 & 0.54 & 8.83 & 84.05 & 32.68 & 119.62 \\
\hline $\begin{array}{c}\text { Arunachal } \\
\text { Pradesh }\end{array}$ & 21.22 & 0.22 & 15.51 & 2.35 & 4.46 & 48.75 & 7.09 & 56.34 \\
\hline Assam & 14.47 & 0.51 & 23.28 & 1.06 & 4.32 & 41.70 & 41.34 & 86.96 \\
\hline Manipur & 8.57 & 1.21 & 11.24 & 4.06 & 7.23 & 34.21 & 33.01 & 70.34 \\
\hline Meghalaya & 7.91 & 0.19 & 8.28 & 0.92 & 3.37 & 21.34 & 6.00 & 27.97 \\
\hline Mizoram & 44.26 & 0.01 & 22.22 & 3.56 & 2.45 & 85.21 & 0.56 & 85.47 \\
\hline Nagaland & 7.80 & 0.00 & 7.52 & 3.01 & 3.46 & 24.58 & 7.18 & 32.37 \\
\hline Sikkim & 29.91 & 14.68 & 36.67 & 3.11 & 9.77 & 95.23 & 16.14 & 112.38 \\
\hline Tripura & 23.52 & 1.55 & 59.18 & 0.88 & 7.22 & 83.23 & 35.10 & 121.47 \\
\hline Goa & 41.51 & 0.38 & 4.91 & 2.60 & 20.38 & 82.97 & 22.40 & 107.25 \\
\hline Gujarat & 49.81 & 1.62 & 6.14 & 3.76 & 11.38 & 90.93 & 14.92 & 106.95 \\
\hline Maharashtra & 66.97 & 6.37 & 6.40 & 2.90 & 13.73 & 117.88 & 3.36 & 121.26 \\
\hline $\begin{array}{l}\text { Andhra } \\
\text { Pradesh }\end{array}$ & 94.15 & 10.05 & 0.93 & 0.56 & 1.28 & 138.97 & 1.40 & 149.94 \\
\hline Karnataka & 75.35 & 0.62 & 2.15 & 2.42 & 3.78 & 113.70 & 2.04 & 115.47 \\
\hline Kerela & 79.74 & 3.80 & 1.34 & 2.77 & 15.22 & 131.41 & 22.27 & 145.34 \\
\hline Tamil Nadu & 89.89 & 1.52 & 0.68 & 2.53 & 6.36 & 135.89 & 3.14 & 138.79 \\
\hline
\end{tabular}


Table 9 : Estimated number of births averted and percent increase of births in the absence of contraception using Bongaarts model

\begin{tabular}{|c|c|c|c|c|c|c|c|}
\hline States & $\begin{array}{c}\text { Women in } \\
\text { age group } \\
\text { 15-49 }\end{array}$ & $\begin{array}{c}\text { Number } \\
\text { of births }\end{array}$ & $\mathrm{u}$ & $\mathrm{e}$ & $\mathrm{Cc}$ & $\begin{array}{c}\text { Births } \\
\text { Averted }\end{array}$ & $\begin{array}{c}\text { Percent } \\
\text { Increase }\end{array}$ \\
\hline Delhi & 3349 & 697 & 0.669 & 0.86071 & 0.37812 & 1146 & 164 \\
Haryana & 2790 & 737 & 0.634 & 0.92873 & 0.36408 & 1287 & 175 \\
Himachal & 3193 & 604 & 0.726 & 0.94521 & 0.25888 & 1729 & 286 \\
Pradesh & & & & & & & \\
Jammu and & 3281 & 728 & 0.526 & 0.91971 & 0.47753 & 797 & 109 \\
Kashmir & & & & & & & \\
Punjab & 3681 & 759 & 0.633 & 0.90348 & 0.38235 & 1226 & 162 \\
Rajasthan & 3892 & 1218 & 0.472 & 0.95293 & 0.51424 & 1151 & 94 \\
Uttaranchal & 2953 & 454 & 0.593 & 0.90261 & 0.42193 & 622 & 137 \\
Chhattisgarh & 3810 & 966 & 0.532 & 0.97862 & 0.43773 & 1241 & 128 \\
Madhya & 6427 & 1944 & 0.559 & 0.96884 & 0.41509 & 2739 & 141 \\
Pradesh & & & & & & & \\
Uttar & 12183 & 4453 & 0.436 & 0.90034 & 0.57605 & 3277 & 74 \\
Pradesh & & & & & & & \\
Bihar & 3818 & 1484 & 0.341 & 0.96021 & 0.64637 & 812 & 55 \\
Jharkhand & 2983 & 985 & 0.357 & 0.95434 & 0.63204 & 573 & 58 \\
Orrisa & 4540 & 1093 & 0.507 & 0.96141 & 0.47357 & 1215 & 111 \\
West Bengal & 6794 & 1569 & 0.712 & 0.94208 & 0.27557 & 2125 & 263 \\
Arunachal & 1647 & 490 & 0.432 & 0.94048 & 0.56121 & 383 & 78 \\
Pradesh & & & & & & & \\
Assam & 3840 & 968 & 0.565 & 0.93759 & 0.42788 & 1294 & 134 \\
Manipur & 4512 & 1212 & 0.487 & 0.90572 & 0.52363 & 1103 & 91 \\
Meghalaya & 2124 & 716 & 0.243 & 0.92514 & 0.75721 & 230 & 32 \\
Mizoram & 1791 & 487 & 0.599 & 0.97122 & 0.37170 & 823 & 169 \\
Nagaland & 3896 & 1387 & 0.297 & 0.92844 & 0.70219 & 588 & 42 \\
Sikkim & 2127 & 423 & 0.576 & 0.88172 & 0.45150 & 514 & 121 \\
Tripura & 1906 & 400 & 0.657 & 0.90902 & 0.35500 & 727 & 182 \\
Goa & 3464 & 604 & 0.482 & 0.92984 & 0.51596 & 567 & 94 \\
Gujarat & 3729 & 901 & 0.666 & 0.95717 & 0.31153 & 1991 & 221 \\
Maharashtra & 9334 & 1998 & 0.669 & 0.96379 & 0.30364 & 3582 & 229 \\
Andhra & 7128 & 1336 & 0.676 & 0.99843 & 0.27106 & 3593 & 269 \\
Pradesh & & & & & & & \\
Karnataka & 6008 & 1284 & 0.636 & 0.99016 & 0.31988 & 2730 & 213 \\
Kerela & 3566 & 611 & 0.686 & 0.96883 & 0.28222 & 1554 & 254 \\
Tamil Nadu & 5919 & 1016 & 0.614 & 0.98642 & 0.34589 & 1921 & 189 \\
\hline
\end{tabular}




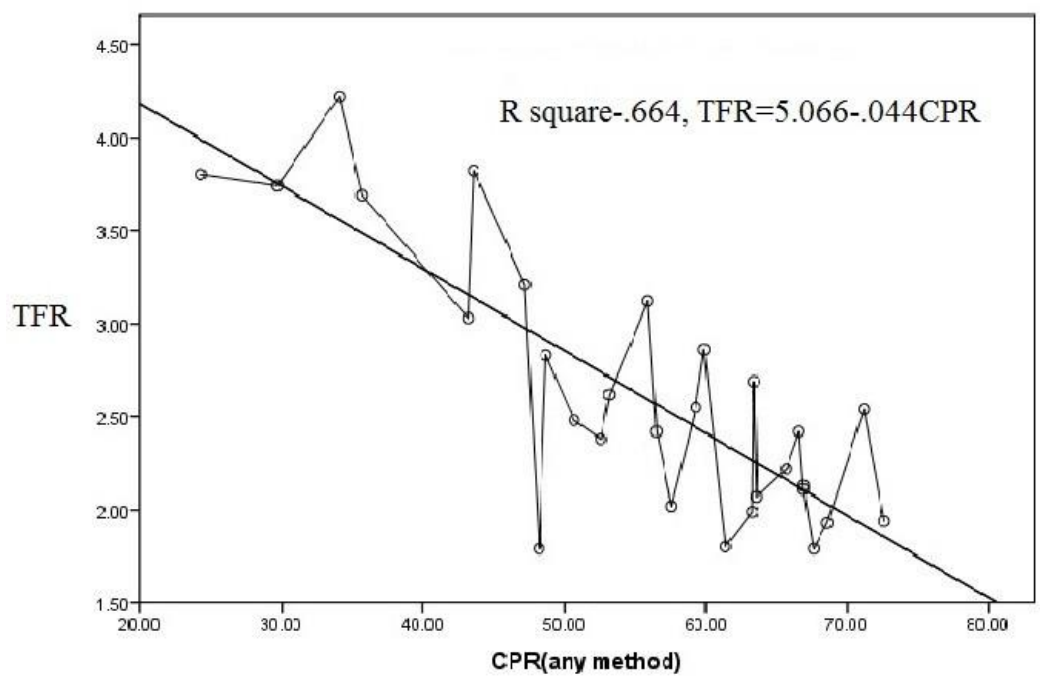

Figure $1:$ Observed relationship between total fertility rate and contraceptive prevalence rate

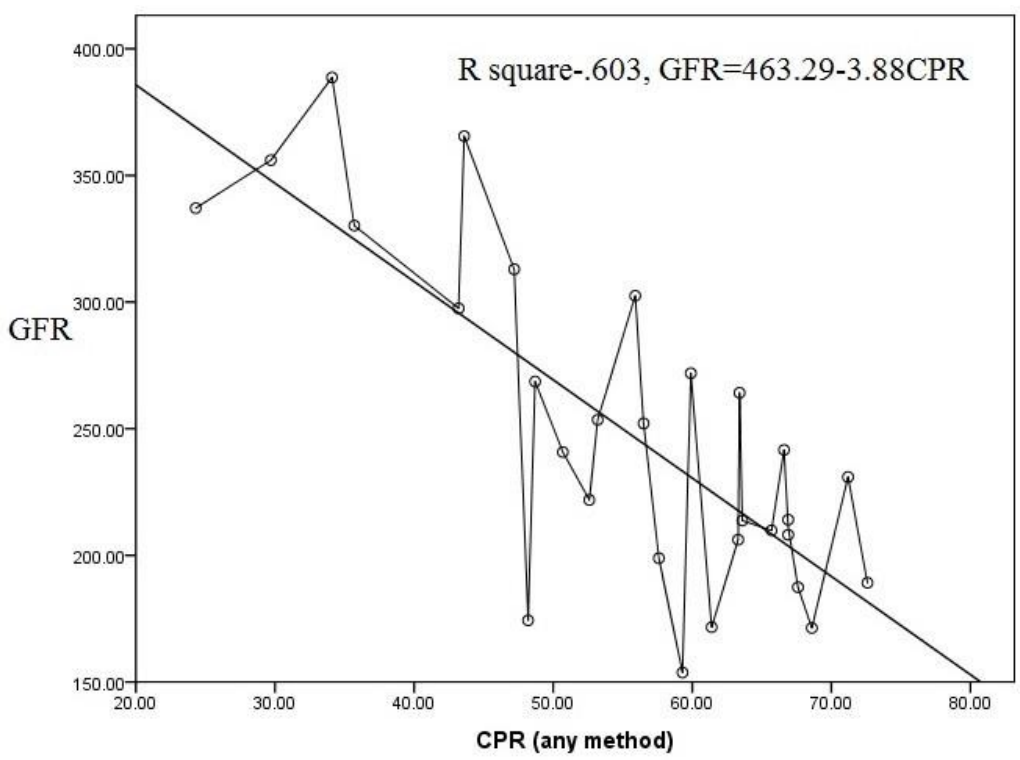

Figure $2:$ Observed relationship between general fertility rate and contraceptive prevalence rate 


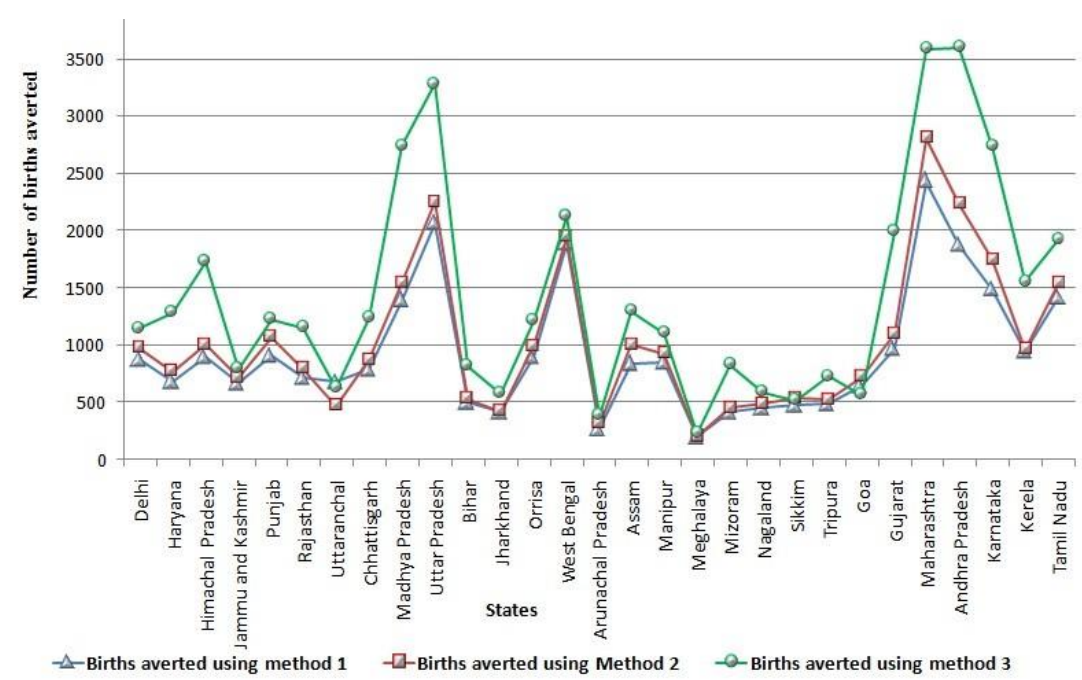

Figure $3:$ Estimated number of births averted due to family planning practices in 29 states of India

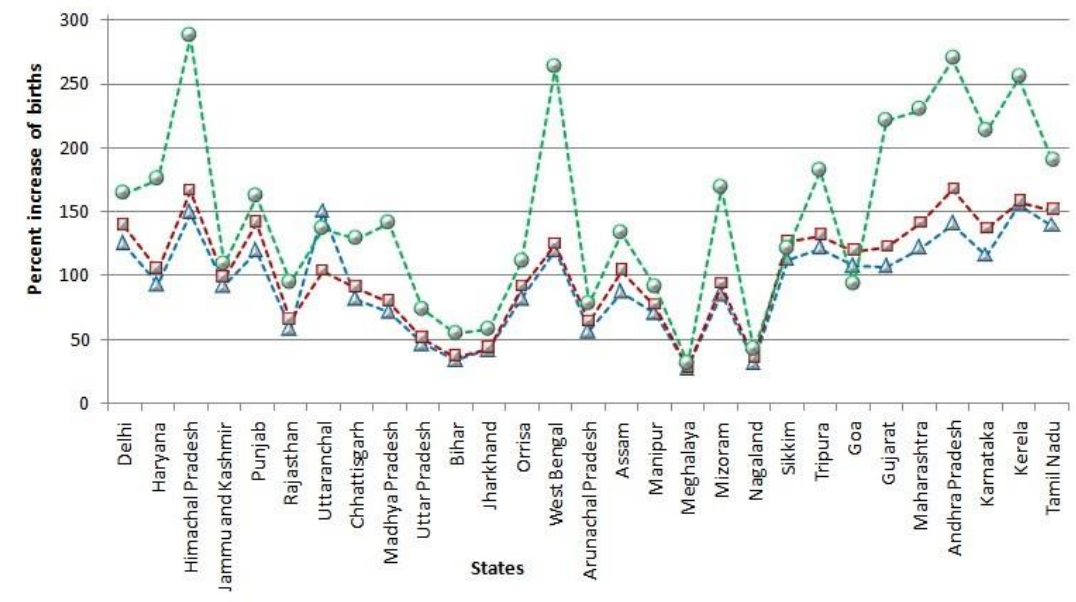

$-\Delta-\%$ increaseof births using method $1-\square-\%$ increase of births using method $2-0-\%$ increase of births using method 3

Figure 4 : Estimated percent increase of births in the absence of contraception in 29 states of India 
676 INDIRECT METHOD OF ESTIMATION OF TOTAL FERTILITY RATE AND STUDY ABOUT BIRTHS AVERTED DUE TO FAMILY PLANNING PRACTICES IN INDIA: A RIDGE REGRESSION APPROACH 